\title{
Geology of the Recently Discovered Hardy Lake Kimberlites, NWT
}

\author{
McKinlay, F.T. ${ }^{1}$, Scott Smith, B.H. ${ }^{2}$, de Gasparis, S. ${ }^{3}$ and Kong, J. ${ }^{4}$
}

1. Monopros Limited, P.O. Box 2520, Yellowknife, NT, X1A 2P8, Canada

2. Scott-Smith Petrology Inc., 2555 Edgemont Boulevard, North Vancouver, BC, V7R 2M9, Canada

3. Palynex Canada, 2503-12th Avenue S.W., Calgary, Alberta, T3C 0S3, Canada

4. Monopros Limited, WaterPark Place, 10 Bay Street, Suite 1510, Toronto, ON., M5J 2R8, Canada

\section{Introduction}

Exploration undertaken from 1991 to 1994 by Monopros Limited, a subsidiary of De Beers Consolidated Mines Limited, on the Hardy Lake property led to the discovery of seven kimberlites (McKinlay et al., 1997). Since then another three bodies have been found. The Hardy Lake (HL) property is located $\sim 350 \mathrm{~km}$ NNE of Yellowknife in the Northwest Territories, Canada. The HL bodies form an eastern extension of the Lac de Gras kimberlite province(s). This area occurs within the Slave Geological Province, an Archaean craton. The kimberlites are hosted by granite and quartz monzonite. The area is covered by glacial deposits from which kimberlite indicator minerals were recovered to aid in the discovery of the kimberlites. The indicator minerals were dispersed in a NW direction by glaciers influenced by the Keewatin Ice Divide centred on the west side of Hudson Bay. The kimberlites all contain microdiamonds, some in significant quantities but the bodies are small, being less than 4 ha. in size.

\section{Mantle-derived xenocrysts}

In the HL kimberlites mantle-derived xenocrysts vary in abundance. After olivine, garnet is the dominant mineral. Chromite is generally present in moderate abundances and chrome diopside varies from relatively abundant to rare. In most of the HL kimberlites ilmenite is rare to absent. Most of the garnets are lherzolitic varieties with $\mathrm{Cr}_{2} \mathrm{O}_{3}$ contents ranging up to $12 \mathrm{wt}$.\%. $\mathrm{TiO}_{2}$-rich and $\mathrm{TiO}_{2}$-poor garnets are both present. Up to $11 \%$ of the garnets in any one kimberlite classify as G10. Up to $8 \%$ of the garnets are eclogitic and minor megacrystic types also occur. The incompatible element $(\mathrm{Ti}, \mathrm{Zr})$ compositions of the garnets show that the kimberlites sampled depleted lithosphere. The garnets commonly have kelyphitic rims. Chromites from HL are comparable in composition to those typically found in kimberlites elsewhere and up to $35 \%$ of the grains are similar to diamond inclusion chromites. The latter, together with the common G10 garnets, indicate that the kimberlites sampled the diamond stability field in the mantle which is consistent with the presence of microdiamonds. The kimberlitic ilmenites have $\mathrm{Cr}_{2} \mathrm{O}_{3}$ contents between 1-4 wt.\% and are considered to be metasomatic in origin. The chrome diopsides present are derived from peridotites. A few ultramafic xenoliths were observed in the drillcore.

\section{Geology of the kimberlites}

The HL occurrences are classified as kimberlites (sensu stricto, Group 1 or archetypal). They contain two generations of olivine which are set in groundmasses composed of monticellite, spinel, perovskite, mica, serpentine and carbonate. The ten kimberlite bodies form two contrasting groups, each with distinct textural characteristics :

A. the larger bodies which are infilled with inhomogeneous, partly bedded, volcaniclastic kimberlite, and

B. the smaller bodies which are composed of fresh internally uniform hypabyssal kimberlite that occurs as pipes and small sheet-like intrusions. 
Group A, comprising the two most northerly bodies (HL01 and HL02), are volcaniclastic kimberlites composed mainly of single grains of olivine set in a fine grained non-magmatic interclast matrix which, in many parts of the kimberlite bodies, resembles shale. Juvenile pyroclastic lapilli are present, mainly in the coarser grained kimberlite. The rocks vary from matrix supported F- to F-MK to clast supported CK (terminology after Field and Scott Smith, this volume). Some bedding, including graded beds, are present. Most observed beds are $<1 \mathrm{~m}$ thick (but may range up to $10 \mathrm{~m}$ ). Each of the pipes displays specific characteristics, for example, with respect to the mantlederived xenocryst and country rock xenolith contents, and in the nature of the inter-clast matrices. The differences show the unique nature of the two volcanic centres. The kimberlites contain xenoliths of granite but inclusions of shale are much more common. The paucity of granite clasts shows that the pipes were excavated into the country rock prior to their infilling by kimberlitic material. The shale must have been derived from sedimentary country rocks that covered the Archaean basement at the time of kimberlite emplacement but have since been eroded. Many of the sediment xenoliths were poorly consolidated when they were incorporated into the kimberlite. Some fossil wood is also present. The hypabyssal kimberlites (Group B) vary from sparsely macrocrystic to macrocrystic in texture. They contain common xenoliths of granite (usually $<1 \mathrm{~cm}$ ) but in three of the kimberlites there are also rare irregular xenoliths that resemble sedimentary material.

\section{Palynology}

Palynomorphs recovered from individual sedimentary clasts hosted by the volcaniclastic kimberlites usually have restricted age ranges between 3 and $10 \mathrm{Ma}$. (99-94, 97-96, 96-93, 93-90, 88-85, 84-75, 78-67 and 74-67 Ma.). These data suggest that the sediment clasts represent xenoliths derived from many different stratigraphic units of the now eroded sedimentary cover rocks. The total range in ages of the sediments (99-67 Ma.) spans most of the Upper Cretaceous showing that during this period the Western Interior Seaway extended over this area of the Slave. It is probably not coincidental that this is also the period of overall highest sea levels in the Seaway. Similar results were found by Nassichuk and McIntyre (1995) for other pipes in the Lac de Gras area west of HL. It is interesting to consider what thickness of sediments may have been present at the time of kimberlite emplacement and what their possible effect on the near surface emplacement processes would have been in terms of the concepts discussed by Field and Scott Smith (this volume). Another fascinating aspect of these, and other kimberlites in the Lac de Gras area, is why some kimberlites formed volcaniclastic infilled pipes while others are hypabyssal. The HL sediment xenolith data also show that the maximum age of emplacement of these kimberlites is 74-78 Ma..

Samples of the host volcaniclastic kimberlite which contained no macroscopically visible sediment xenoliths all contained microfossils. In contrast to the single sediment xenoliths discussed above, each sample of the host kimberlite yielded palynomorphs with a wide range of ages of between 30 and $60 \mathrm{Ma}$.. This shows that the inter-clast matrix of the volcaniclastic kimberlites is composed of a blend of disseminated shale from mixed stratigraphic sources in the sedimentary cover. This result strongly suggests that the final deposition of the kimberlitic material containing the blended shaly matrix was by resedimentation processes. This conclusion is supported by the presence of probable armoured lapilli and a variety of 'mudballs' composed of a mixture of shale and kimberlitic constituents. The presence of armoured lapilli and 'mudballs' also suggests a wet environment of deposition. The total range in ages of the microfossils found in the host kimberlite is 116-55 Ma. and includes examples younger than those found among the analysed xenoliths. Palynomorphs with age ranges $<67 \mathrm{Ma}$. were only found in HL01. There are two possible explanations for these features. 
Firstly, the kimberlites could be younger than 74-78 Ma.. An age of $52 \mathrm{Ma}$. has been reported for another kimberlite in the Lac de Gras area (Nassichuk and McIntyre, 1995). If so, the uppermost country rock sediments may not have included 67-55 Ma. rocks or the rocks of this age were so poorly consolidated that they disintegrated when incorporated into the kimberlite. It is also possible that the sampling did not include such xenoliths. The second explanation is that the kimberlites were emplaced at 74 Ma.. Heaman et al. (1997) reported an age of $74 \mathrm{Ma}$. for another Lac de Gras kimberlite. If so, the HL pipes could have been infilled by resedimentation over a prolonged period of time, long enough to incorporate palynomorphs from the surface long after the kimberlite eruption.

Most of the microfossils from the sediment xenoliths (97-73 Ma.) are marine. However, the youngest microfossils from each of the host kimberlites are terrestrial (66-55 Ma. at HL01; 74-67 Ma. at HL02). This suggests that the period 74-66 Ma. was a time of regression. This is consistent with the last overall main regression of the Western Interior Seaway which occurred at $71 \mathrm{Ma}$.. After this time terrestrial conditions probably predominated. Given the lack of a precise age of eruption for the HL bodies, the environment at the time of emplacement of the kimberlite cannot be determined.

A few sediment-like xenoliths from two of the hypabyssal kimberlites yielded sparse terrestrial organic material with ages of 108-97, 116-97 and possibly $67 \mathrm{Ma}$.. Further work is required, but the data suggest that the xenoliths contain Cretaceous organisms derived from the sedimentary cover and that the magmatic kimberlite must have penetrated some, or all, of the Cretaceous sediments that were present at the time of emplacement. The magma must then have withdrawn to its present location. Also, the organisms appear to have been subjected to a maximum temperature of only $300^{\circ}$ $\mathrm{C}$ which is unexpected. Possible olivines were observed within some of the xenoliths suggesting that they may not be simple country rock clasts.

\section{Conclusions}

Ten kimberlites were discovered on the HL property which include two volcaniclastic pipes with the remainder being of hypabyssal-facies. Palynology of sedimentary xenoliths from within the volcaniclastics show that the kimberlites were emplaced after 74-78Ma. and that the Great Western Interior Seaway covered this part of the Slave during most of the Cretaceous. The volcaniclastic kimberlites may have been deposited by resedimentation processes (possibly long lived) into a previously excavated pipe. Cretaceous palynomorphs have been recovered from rare xenoliths within hypabyssal kimberlites.

\section{References}

Heaman, L.M., Kjarsgaard, B., Creaser, R.A., Cookenboo, H.O., and Kretschmar, U, 1997, Multiple episodes of kimberlite magmatism in the Slave Province, North America, In: Slave-Northern Cordillera Lithospheric Evolution, University of Calgary, Lithoprobe Report, n. 56, p.14-17.

McKinlay, F.T, Williams, A.C., Scott-Smith, B.H., Kong, J., 1997, An Integrated Exploration Case History for Diamonds, Hardy Lake Project, NWT, In: Gubins, A.G., ed., Proc. of the 4th Decennial International Conference on Mineral Exploration, Toronto, Canada, p.1029-1037.

Nassichuk, W.W., and McIntyre, D.J., 1995, Cretaceous and Tertiary fossils discovered in kimberlites at Lac de Gras in the Slave Province, Northwest Territories, in Current Research 1995-B, Geological Survey of Canada, p.109-114. 